\title{
DEVELOPMENT OF Bemisia tabaci (GENNADIUS,1889) BIOTYPE B ON Lycopersicon spp. GENOTYPES ${ }^{1}$
}

\author{
Marilene Fancelli; José Djair Vendramim ${ }^{3 *}$ \\ ${ }^{2}$ Embrapa Mandioca e Fruticultura, C.P. 007 - CEP: 44380-000 - Cruz das Almas, BA. \\ ${ }^{3}$ Depto. de Entomologia, Fitopatologia e Zoologia Agrícola - USP/ESALQ, C.P. 9 - CEP: 13418-900 - Piracicaba, SP. \\ ${ }^{*}$ Corresponding author <jdvendra@esalq.usp.br>
}

\begin{abstract}
Whiteflies are phytophagous insects, whose nymphs and adults suck the phloem sap, causing direct damage due to host plant weakness. In tomato (Lycopersicon spp.) crops, they are important vectors of limiting fitoviruses. The objective of this study was to determine the effects of Lycopersicon spp. genotypes on Bemisia tabaci (Gennadius, 1889) biotype B development under greenhouse conditions. The evaluated genotypes were LA462 (L. peruvianum), LA716 (L. pennellii), LA1584 (L. pimpinellifolium), LA1609 (L. peruvianum), LA1739 (L. hirsutum), P25 (L. esculentum), PI134417 (L. hirsutum f. glabratum) and Santa Clara (L. esculentum). LA716 was non-preferred for oviposition by the whitefly, which suggests an antixenotic effect. LA1584 showed an antibiotic resistance because nymphal survival was reduced and nymphal developmental time was increased. Antixenotic resistance was observed in LA1739 and PI134417, based on a reduction of oviposition. PI134417 also reduced nymphal survival, which suggests an antibiotic effect, but LA1739 was suitable for insect development. LA1609 was highly preferred for oviposition, however it reduced insect survival. P25 and Santa Clara ( $L$. esculentum) were highly preferred for oviposition.

Key words: Bemisia argentifolii, Aleyrodidae, whitefly, biology, tomato
\end{abstract}

\section{DESENVOLVIMENTO DE Bemisia tabaci (GENNADIUS, 1889) BIÓTIPO B EM GENÓTIPOS DE Lycopersicon spp.}

\begin{abstract}
RESUMO: Moscas-brancas são insetos fitófagos que, tanto na fase adulta como na imatura, sugam a seiva do floema, acarretando danos diretos em função do enfraquecimento das plantas hospedeiras. Na cultura do tomate, também são importantes transmissoras de viroses. Este trabalho foi conduzido com o objetivo de estudar o desenvolvimento de Bemisia tabaci (Gennadius, 1889) biótipo B em genótipos de Lycopersicon spp., em casa de vegetação. Os genótipos estudados foram LA462 (L. peruvianum), LA716 (L. pennellii), LA1584 (L. pimpinellifolium), LA1609 (L. peruvianum), LA1739 (L. hirsutum), P25 (L. esculentum), PI134417 (L. hirsutum f. glabratum) e Santa Clara (L. esculentum). LA716 proporcionou redução na oviposição do inseto, indicando a ocorrência de antixenose. LA1584, além de prolongar a duração da fase ninfal, reduziu a viabilidade dessa fase, o que sugere a ocorrência de antibiose. Antixenose foi constatada em LA1739 e PI134417, com base na redução da oviposição. PI134417 reduziu a viabilidade ninfal, sugerindo efeito antibiótico desse material sobre o inseto. LA1739, apesar de reduzir a oviposição, foi adequado ao desenvolvimento do inseto. LA1609 foi altamente preferido para oviposição, contudo reduziu a viabilidade do inseto. P25 e Santa Clara (L. esculentum) foram altamente preferidos para oviposição.

Palavras-chave: Bemisia argentifolii, Aleyrodidae, mosca-branca, biologia, tomate
\end{abstract}

\section{INTRODUCTION}

The increasing importance of the whiteflies of the genus Bemisia has been associated to the introduction and widespread of the biotype $B$. This biotype differs from the biotype $A$ due to its higher fecundity, wider host plant range, resistance to several insecticides and ability to promote plant physiological disorders, such as squash silverleaf (Brown et al., 1965; Costa \& Brown, 1990; De Barro, 1995). The taxonomic status of biotype $B$ is still reason of discussion (Brown et al.,1995; Rosell et al., 1997) despite strong evidence for separate status, including the description as Bemisia argentifolii (Bellows et al.,1994).
In Brazil, Lourenção \& Nagai (1994) found large populations of $B$. tabaci in the State of São Paulo, in vegetable and ornamental crops, associated with the symptoms of the squash silverleaf and the tomato irregular ripening. Because of the characteristic infestations and damage severity, the presence of Bemisia tabaci biotype B in Brazil was suggested by the authors.

In tomato, besides the damage caused by nymphal and adult feeding, this insect can transmit limiting plant viruses, and cause a physiological disorder (irregular ripening on fruits), depreciating the commercial value of the product (Brown \& Bird, 1992; Schuster et al., 1990). In the 1990-1991 tomato crop season, control

${ }^{1}$ Part of the Thesis of the first author, presented to USP/ESALQ - Piracicaba, SP, Brazil. 
costs plus the damage resulting from this pest and the diseases it transmits reached about 125 millions dollars (Norman et al., s/d).

Because $B$. tabaci biotype $B$ is widely polyphagous, insect development can be affected by the host plant (Drost et al., 1998). Coudriet et al. (1985), without mentioning insect biotype, recorded $30 \%$ faster development of $B$. tabaci on lettuce, cucumber, eggplant and squash than on broccoli and carrot, at $25.7^{\circ} \mathrm{C}$. Later, Drost et al. (1998) suggested that the insect in the Coudriet et al. (1985) study might be $B$. tabaci biotype A. Boiça Jr. \& Vendramim (1986) found differences among bean genotypes in relation to their effect on the incubation period, nymphal stage and egg-adult cycle of $B$. tabaci in rainfall season. However in dry season, there were no differences among bean genotypes, except for the duration of nymphal period. The authors reported shorter B. tabaci cycles on Goiano Precoce, Carioca and G 2618, but on Bolinha, the cycle was longer, suggesting the occurrence of antibiosis. No differences in the development cycle were reported between two populations reared on cotton and poinsettia (Bethke et al., 1991), althought the population from poinsettia was characterized later as $B$. tabaci biotype B (Drost et al., 1998).

The development of $B$. argentifolii on five hosts was studied at $25^{\circ} \mathrm{C}$ (Tsai \& \& Wang, 1996), ranging from 17.3 to 20.9 days, and the nymphal survival from 88.7 to $45.8 \%$. Yee \& Toscano (1996) concluded that the $B$. argentifolii life cycle (from egg to adult) was not affected by the host under greenhouse conditions at $27^{\circ} \mathrm{C}$. However, when the temperature varied between 11 and $35^{\circ} \mathrm{C}$, the insect development was slower on alfafa (39.4 dias) than on cotton (37.4 dias). Morillo \& Marcano (1997) recorded differences among 10 tomato genotypes in relation to all $B$. tabaci phases. The life cycle ranged from 32.3 to 37.8 days at temperature of $26^{\circ} \mathrm{C}$ and relative humidity of $70 \%$.

According to Bas et al. (1992) and Romanow et al. (1991), the most suitable criteria for antibiosis characterization in tomatoes were the survival and the population density determinated at several time intervals.

França et al. (1999), evaluating germoplasms of eggplant (161 accessions), muskmelon (120 accessions) and tomato (10 accessions) for the presence of whitefly eggs, nymphs and adults in free-choice tests, observed genetic variability in resistance to the insect in the three horticultural species. The objective of the current study was to analyze the development of $B$. tabaci biotype $B$ on eight tomato genotypes to determine if similar variability was present.

\section{MATERIAL AND METHODS}

The research was conducted in Piracicaba, SP, Brazil, under greenhouse conditions. During the experiment, the temperature and the relative humidity ranged from 8 to $24^{\circ} \mathrm{C}$ and from 40 to $100 \%$, respectively.

The Lycopersicon genotypes evaluated were LA462 (L. peruvianum), LA716 (L. pennellii), LA1584 (L. pimpinellifolium), LA1609 (L. peruvianum), LA1739 (L. hirsutum), P25 (L. esculentum), PI134417 (L. hirsutum f. glabratum) and Santa Clara (L. esculentum). The insects used in the study were obtained from a stock colony maintained by the Entomology Section of Instituto Agronômico de Campinas (IAC), previously identified as B. tabaci biotype B by Dr. Judith K. Brown, University of Arizona, USA. The whitefly stock colony was reared on soybean and poinsettia.

The experimental design was a randomized complete block with three replications, consisting of three tomato leaflets on the third or fourth leaf from the top of the plant. Adults of whiteflies (50 couples) were aspirated from the rearing stock and transferred to a voile cage (Souza \& Vendramim, 2000), where they were allowed to oviposit for 24 hours. At the end of the nymphal development, the infested leaves were again enclosed by the voile cage in order to confine the emerging adults. Responses studies were number of eggs and egg viability, incubation period, number of nymphs and nymphal viability (based on the exuviae presence). Egg and nymph numbers were counted using a handlens (20x). The tomato leaf $\mathrm{pH}$ was determinated, using 2-g samples of leaf wet mass crushed in $5 \mathrm{~mL}$ of water $(\mathrm{pH}=7.0)$. The data were submitted to analysis of variance and the means were compared by Tukey test $(P \leq 0.05)$.

\section{RESULTS AND DISCUSSION}

Whitefly oviposition was influenced by tomato genotype. LA716 showed the lowest number of eggs per leaflet (2.4) differing from the values on LA1609 (75.7) and on Santa Clara (64.2) (Table 1). The numbers on the other genotypes ranged from 26.4 to 47.9 eggs per leaflet. In relation to the incubation period, the genotypes did not differ and the mean value was about 11 days (Table 1). Egg viability was affected by genotype, the lowest value, was recorded on LA1609 (74.7\%), which differed from those on LA1584 (95.8\%), PI134417 (93.5\%) and on P25 (92.2\%). The other genotypes ranged from 81.0 to $89.0 \%$ (Table 1). It was not possible to evaluate the incubation period and egg viability of $B$. tabaci biotype B on LA716 due to the insufficient number of replications.

The genotypes also differed in relation to the number of nymphs and nymphal viability, but not in relation to the nymphal period (Table 2 ). The lowest number of nymphs (1.0) was recorded on LA716, differing from those on Santa Clara (57.3), LA1609 (56.3) and P25 (44.3). Intermediate values (24.1 to 36.3) were observed on the other genotypes, which did not differ from the extreme values (Table 2). There were no 
differences among genotypes regarding to the nymphal period (Table 2). The lowest nymphal viability (31.2\%), observed on LA1584, differed only from LA1739 (86.9\%). Intermediate values (42.3 to $80.4 \%$ ) occurred with the other genotypes. Differences were not recorded among genotypes concerning the duration of immature phase of $B$. tabaci biotype B (Figure 1). The genotypes also did not affect the insect survival (eggadult) (Figure 1).

Under laboratory conditions, Morillo \& Marcano (1997) observed 27.5 to $119.5 \mathrm{~B}$. tabaci eggs per leaflet on tomato genotypes, 48 hours after the infestation. In our study, the oviposition was greater, ranging from 2.4 to 75.7 for a 24-hour interval (Table 1). Morillo \& Marcano (1997) found differences among genotypes in relation to the duration of all phases of the insect development. In our study, this was not the case, probably due to the different essay conditions, including the genotypes. However, in relation to $T$. vaporariorum developmental period, differences among genotypes were very small, and length of developmental period was not suitable for antibiosis evaluation in tomato crop (Romanow et al., 1991; Bas et al., 1992).

Antixenotic resistance was detected on LA1739 and PI134417, based on reduction of oviposition. However, it is impossible to reject antibiosis as the resistance mechanism in these genotypes because of the negative effects of these genotypes on egg and nymphal viability. On LA1584, the number of eggs was intermediate, demonstrating a certain degree of antixenosis for oviposition, and low nymphal viability occurred on this material (Table 2). Most nymphs died during the initial instars, suggesting antibiosis. However, antixenosis cannot be discarded as the mechanism for resistance. Antixenosis is mediated by chemical, physical and morphological factors (Lara, 1991). A tendency toward longer nymphal phase (Table 2) could be the result of low quality of LA1584 for the insect feeding, reinforcing the antibiosis hypothesis.

The reduction in oviposition on LA716 indicates intense antixenotic effect (Table 1). It was impossible to estimate the effect of the genotype on the insect development due to the small insect number. According to published reports, the resistance mechanism in this Lycopersicon species is related to the antixenosis for oviposition, mediated by acylsugars found in the glandular trichome exudate and dependent on the acylsugar concentration (Barten et al., 1994; Nombela et al., 2000). França et al. (1998 and 1999) recorded the lowest occurrence of $B$. argentifolii eggs and nymphs on tomato accession CNPH 790. The authors observed that adults of whitefly were trapped and killed by the exudate released by the glandular trichomes. The

Table 1 - Mean $( \pm S E M)^{1}$ number of eggs per leaflet, incubation period and egg viability of Bemisia tabaci biotype $B$ on tomato genotypes under greenhouse conditions. Piracicaba, SP, 2000.

\begin{tabular}{|c|c|c|c|}
\hline Genotype & Number of eggs & Incubation period & Viability \\
\hline & & --------- day ---------- & -------------- \% -------------- \\
\hline LA716 & $2.4 \pm 2.4 \mathrm{c}$ & not analyzed & not analyzed \\
\hline PI1 34417 & $26.4 \pm 9.4 b c$ & $11.3 \pm 0.2 \mathrm{a}$ & $93.5 \pm 2.4 \mathrm{a}$ \\
\hline LA1739 & $28.2 \pm 12.2 b c$ & $11.1 \pm 0.1 \mathrm{a}$ & $81.0 \pm 5.8 a b$ \\
\hline LA462 & $35.6 \pm 1.5 \mathrm{abc}$ & $11.5 \pm 0.1 \mathrm{a}$ & $86.5 \pm 2.3 a b$ \\
\hline LA1584 & $37.9 \pm 4.6 \mathrm{abc}$ & $11.3 \pm 0.1 \mathrm{a}$ & $95.8 \pm 0.8 \mathrm{a}$ \\
\hline P25 & $47.9 \pm 6.0 \mathrm{abc}$ & $11.2 \pm 0.1 \mathrm{a}$ & $92.2 \pm 2.2 \mathrm{a}$ \\
\hline Santa Clara & $64.2 \pm 14.3 a b$ & $11.4 \pm 0.2 \mathrm{a}$ & $89.0 \pm 3.9 a b$ \\
\hline LA1609 & $75.7 \pm 10.7 a$ & $11.4 \pm 0.1 \mathrm{a}$ & $74.7 \pm 1.1 \mathrm{~b}$ \\
\hline
\end{tabular}

${ }^{1}$ Means within a column followed by the same letter do not differ by Tukey test $(P \leq 0,05)$.

Table 2 - Mean ( \pm SEM) number of nymphs, nymphal period and viability of Bemisia tabaci biotype $B$ on tomato genotypes and tomato leaf $\mathrm{pHs}$ under greenhouse conditions. Piracicaba, SP, 2000.

\begin{tabular}{lcccc}
\hline Genotype & $\mathrm{pH}$ & Number of nymphs & Duration & Viability \\
\hline LA716 & & & - & \\
PI134417 & 5.31 & $1.0 \pm 1.0 \mathrm{~b}$ & not analyzed & not analyzed \\
LA1739 & 5.87 & $24.6 \pm 8.5 \mathrm{ab}$ & $24.6 \pm 0.7 \mathrm{a}$ & $43.6 \pm 15.0 \mathrm{ab}$ \\
LA462 & 5.97 & $24.1 \pm 11.8 \mathrm{ab}$ & $24.2 \pm 0.9 \mathrm{a}$ & $86.9 \pm 2.1 \mathrm{a}$ \\
LA1584 & 5.43 & $30.8 \pm 1.9 \mathrm{ab}$ & $24.2 \pm 0.8 \mathrm{a}$ & $80.4 \pm 8.3 \mathrm{ab}$ \\
P25 & 5.84 & $36.3 \pm 4.5 \mathrm{ab}$ & $27.2 \pm 0.5 \mathrm{a}$ & $31.2 \pm 8.2 \mathrm{~b}$ \\
Santa Clara & 5.72 & $44.3 \pm 6.4 \mathrm{a}$ & $25.4 \pm 0.5 \mathrm{a}$ & $45.5 \pm 8.5 \mathrm{ab}$ \\
LA1609 & 5.89 & $57.3 \pm 13.5 \mathrm{a}$ & $24.7 \pm 1.0 \mathrm{a}$ & $66.8 \pm 8.8 \mathrm{ab}$ \\
\hline
\end{tabular}

${ }^{1}$ Means within a column followed by the same letter do not differ by Tukey test $(P \leq 0,05)$. 


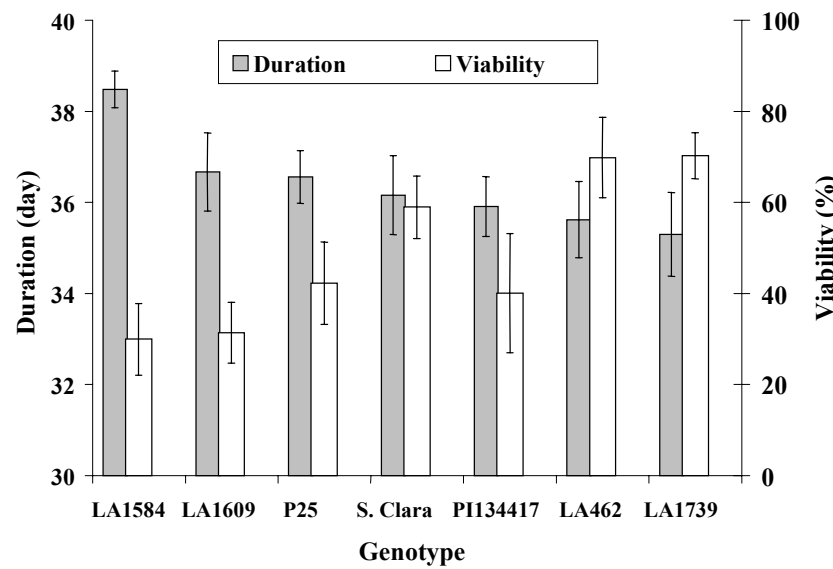

Figure 1- Mean ( \pm SEM) duration and viability of the immature phase of Bemisia tabaci biotype B on tomato genotypes under greenhouse conditions. Piracicaba, SP, 2000.

intermediate level of oviposition recorded on LA462, indicates that antixenosis occurs, but we can not reject the possibility of antibiosis as the resistance mechanism because of the effects on the egg and nymphal viability (Tables 1 and 2).

LA1609 was highly preferred for oviposition (Table 1). This may be due, in part, to the high leaf $\mathrm{pH}$ in this genotype (Table 2), but not exclusively to this factor. According to Berlinger et al. (1983), leaf pH affects host plant selection by $B$. tabaci, which prefers cotton leaves with $\mathrm{pH}$ above 6 . Despite the oviposition preference, LA1609 interfered negatively on the egg and nymphal survival (Tables 1 and 2), indicating that antibiosis occurs. The mortality affected later stages of the nymphal development and in many cases, nymphs were infected by Cladosporium sp. The genotypes P25 and Santa Clara were highly preferred for oviposition (Table 1). However, based on reduction of the nymphal viability (Table 2), antibiosis is the resistance mechanism in these genotypes.

Since number of eggs on leaflets was not standardized, the number of nymphs reported herein may be related to the suitability of the leaflet microclimate for egg development or epidermal characteristics that facilitate or not egg desiccation (Wagner, 1995). Either of these conditions may have interfered with the antixenotic and antibiotic effects.

Based on our results, LA716 and PI134417 are resistant to whitefly through an antixenotic effect. LA1584 showed high level of antibiosis. The incorporation of resistance factors present on wild genotypes in tomato breeding programs is a promising strategy in whitefly control, since the wild species are compatible with $L$. esculentum. As for $L$. pennellii, the identification of the Quantitative Trait Loci (QTL) responsible for the acylsugars composition and levels would allow the selection of germplasm with desirable characteristics, that is, pest resistance and low density of glandular trichomes (Mutschler et al., 1996).

\section{ACKNOWLEDGEMENTS}

To Embrapa Hortaliças, Instituto Agronômico de Campinas, and to the University of California-Davis for providing seeds of tomato genotypes. To the biologist Solange Aparecida Vieira, for assistance in identification of the fungus associated to the nymphs of the whiteflies.

\section{REFERENCES}

BARTEN, J.H.M.; THOME, C.H.; STEVENS, M.R.; SCHUSTER, D.J.; SCOTT, J.W.; CHAMBLISS, O.L. Evaluating resistance in tomato to the silverleaf whitefly, Bemisia argentifolii. Phytoparasitica, v.22, p.330-331, 1994.

BAS, N.; MOLLEMA, C.; LINDHOUT, P. Resistance in Lycopersicon hirsutum f. glabratum to the greenhouse whitefly (Trialeurodes vaporariorum) increases with plant age. Euphytica, v.64, p.189-195, 1992.

BERLINGER, M.J.; MAGAL, Z.; BENZIONI, A. The importance of $\mathrm{pH}$ in food selection by the tobacco whitefly, Bemisia tabaci. Phytoparasitica, v.11, p.151-160, 1983.

BETHKE, J.A.; PAINE, T.D.; NUESSLY, G.S. Comparative biology, morphometrics, and development of two populations of Bemisia tabaci (Homoptera: Aleyrodidae) on cotton and poinsettia. Annals of the Entomological Society of America, v.84, p.407-411, 1991.

BOIÇA JR., A.L.; VENDRAMIM, J.D. Desenvolvimento de Bemisia tabaci (Gennadius, 1889) (Homoptera: Aleyrodidae) em genótipos de feijão (Phaseolus vulgaris L.) Anais da Sociedade Entomológica do Brasil, v.15, p.231-238, 1986.

BROWN, J.K.; BIRD, J. Whitefly-transmitted geminiviruses and associated disorders in the Americas and the Caribbean Basin. Plant Disease, v.76, p.220-225, 1992.

BROWN, J.K.; FROHLICH, D.R.; ROSELL, R.C. The sweetpotato or silverleaf whiteflies: biotypes of Bemisia tabaci or a species complex? Annual Review of Entomology, v.40, p.511-534, 1995.

COSTA, H.S.; BROWN, J.K. Variability in biological characteristics, isozyme patterns and virus transmission among populations of Bemisia tabaci Genn. in Arizona. Phytopathology, v.80, p.888, 1990.

COUDRIET, D.L.; PRABHAKER, N.; KISHABA, A.N.; MEYERDIRK, D.E. Variation in developmental rate on different hosts and overwintering of the sweetpotato whitefly, Bemisia tabaci (Homoptera: Aleyrodidae). Environmental Entomology, v.14, p.516-519, 1985.

DE BARRO, P.J. Bemisia tabaci biotype $\mathbf{B}$ : a review of its biology, distribution and control. 2.ed. Canberra: CSIRO, 1995. 58p. (Technical Paper, 36).

DROST, Y.C.; VAN LENTEREN, J.C.; VAN ROERMUND, H.J.W. Life-history parameters of different biotypes of Bemisia tabaci (Hemiptera: Aleyrodidae) in relation to temperature and host plant: a selective review. Bulletin of Entomological Research, v.88, p.219-229, 1998.

FRANÇA, F.H.; VILLAS BOAS, G.L.; PESSOA, H.B.S.V.; GIORDANO, L.B. Avaliação de tomate para resistência à Bemisia argentifolii. In: CONGRESSO BRASILEIRO DE ENTOMOLOGIA, 17., Rio de Janeiro, 1998. Resumos. Rio de Janeiro: Universidade Federal Rural do Rio de Janeiro, 1998. Livro 1, p.89.

FRANÇA, F.H.; VILLAS BOAS, G.L.; REIFSCHNEIDER, F.J.B.; CARVALHO, S.I.C. de; GIORDANO, L. de B. Avaliação dos bancos de germoplasma de berinjela, melão e tomate da Embrapa Hortaliças para resistência à mosca-branca. (Compact disc). In: ENCONTRO LATINO-AMERICANO E DO CARIBE SOBRE MOSCAS BRANCAS E GEMINIVÍRUS, 8., Recife, 1999. Anais. Recife: IPA, 1999. CD-ROM.

LARA, F.M. Princípios de resistência de plantas a insetos. São Paulo: Ícone, 1991. 336p.

LOURENÇÃO, A.L.; NAGAI, H. Surtos populacionais de Bemisia tabaci no Estado de São Paulo. Bragantia, v.53, p.53-59, 1994.

MORILLO, F.E.; MARCANO B., R.V. Estudio del desarrollo de la mosca blanca en diferentes genotipos de tomate. Agronomía Tropical, v.47, p.271286, 1997.

MUTSCHLER, M.A.; DOERGE, R.W.; LIU, S.C.; KUAI, J.P.; LIEDL, B.E.; SHAPIRO, J.A. QTL analysis of pest resistance in the wild tomato Lycopersicon pennellii: QTLs controlling acylsugar level and composition. Theoretical and Applied Genetics, v.92, p.709-718, 1996.

NOMBELA, G.; BEITIA, F; MUÑIZ, M. Variation in tomato host response to Bemisia tabaci (Hemiptera: Aleyrodidae) in relation to acyl sugar content and presence of the nematode and potato aphid resistance gene $\mathrm{Mi}$. Bulletin of Entomological Research, v.90, p.161-167, 2000.

NORMAN, J.W.; RILEY, D.G.; STANSLY, P.A.; ELLSWORTH, P.C.; TOSCANO, N.C. Management of silverleaf whitefly: A comprehensive manual on the biology, economic impact and control tactics. Washington: USDA, s.d. $13 p$. 
ROMANOW, L.R.; PONTI, O.M.B. de; MOLLEMA, C. Resistance in tomato to the greenhouse whitefly: analysis of population dynamics. Entomologia Experimentalis et Applicata, v.60, p.247-259, 1991.

ROSELL, R.C.; BEDFORD, I.D.; FROHLICH, D.R.; GILL, R.J.; BROWN, J.K.; MARKHAM, P.G. Analysis of morphological variation in distinct populations of Bemisia tabaci (Homoptera: Aleyrodidae). Annals of the Entomological Society of America, v.90, p.575-589, 1997.

SCHUSTER, D.J.; MUELLER, T.F.; KRING, J.B.; PRICE, J.F. Relationship of the sweetpotato whitefly to a new tomato fruit disorder in Florida. HortScience, v.25, p.1618-1620, 1990.

SOUZA, A.P. de; VENDRAMIM, J.D. Atividade ovicida de extratos aquosos de meliáceas sobre a mosca branca Bemisia tabaci (Gennadius) biótipo B em tomateiro. Scientia Agricola, v.57, p.403-406, 2000.
TSAI, H.; WANG, K. Development and reproduction of Bemisia argentifolii (Homoptera: Aleyrodidae) on five host plants. Environmental Entomology, v.25, p.810-816, 1996.

WAGNER, T.L. Temperature-dependent development, mortality, and adult size of sweetpotato whitefly biotype B (Homoptera: Aleyrodidae) on cotton. Environmental Entomology, v.24, p.1179-1188, 1995.

YEE, W.L.; TOSCANO, N.C. Ovipositional preference and development of Bemisia argentifolii (Homoptera: Aleyrodidae) in relation to alfafa. Journal of Economic Entomology, v.89, p.870-876, 1996.

Received February 08, 2001 